\author{
우사깔짚에서 발생되는 온실가스 배출량 산정 : 모의 실험결과 \\ 조원실 ${ }^{1} \cdot$ 이진의 $^{1} \cdot$ 박규현 $^{2} \cdot$ 김정대 $^{1} \cdot$ 라창식 $^{1 *}$ \\ ${ }^{1}$ 강원대학교 동물생명과학대학, 춘천시 효자2동 강원대학길 192-1, ${ }^{2}$ 국립축산과학원 수원시 권선구 441-350
}

\title{
Emission Rate of Greenhouse Gases from Bedding Materials of Cowshed Floor: Lab-scale simulation study
}

\author{
Won Sil Cho ${ }^{1}$, Jin Eui Lee ${ }^{1}$, Kyu Hyun Park ${ }^{2}$, Jeong Dae Kim ${ }^{1}$ and Chang Six Ra ${ }^{1}$ * \\ ${ }^{1}$ Department of Animal Life System, College of Animal Life Science, Kangwon National University, Chunchon 200-701, \\ South Korea, ${ }^{2}$ National Institute of Animal Science, RDA, Suwon, 441-350, South Korea
}

\begin{abstract}
To know the emission amount of greenhouse gases from bedding materials of cowshed floor, the emission rates of methane $\left(\mathrm{CH}_{4}\right)$ and nitrous oxide $\left(\mathrm{N}_{2} \mathrm{O}\right)$ gases from a simulated cowshed floor $(\mathrm{SCF})$ with sawdust that manure loading rate into the bedding material could be accurately controlled were assessed in this study. The manure loading rates of Korean beef and Holstein dairy cattle into the SCF of $0.258 \mathrm{~m}^{2}$ surface area with 10 to $15 \mathrm{~cm}$ height sawdust were $1.586 \mathrm{~kg} / \mathrm{m}^{2} / \mathrm{d}$ and 3.588 $\mathrm{kg} / \mathrm{m} 2 / \mathrm{d}$, respectively, and those were calculated on the basis of "Standard model for sustainable livestock" and "Data for excretion amount of manure from livestock". All experiments were done in triplicates in three different seasons (May to July, Sep. to Nov., and Feb. to Apr.) using 12 SCFs. The effects of bedding material thickness on $\mathrm{CH}_{4}$ and $\mathrm{N}_{2} \mathrm{O}$ emission from SCFs for both Korean beef cattle and Holstein dairy cattle were not statistically significant $(\mathrm{p}<0.05)$. Emission amount of $\mathrm{CH}_{4}$ and $\mathrm{N}_{2} \mathrm{O}$ per square meter of SCF for Holstein dairy cattle was 7.5 and 1.2 times higher than that of Korean beef cattle, respectively. The yearly $\mathrm{CH}_{4}$ amount per head was 17.7 times higher in Holstein dairy cattle, obtaining $130.4 \mathrm{~g} /$ head/year from SCF for Holstein dairy cattle and $7.4 \mathrm{~g} /$ head/year from SCF for Korean beef cattle, and $\mathrm{N}_{2} \mathrm{O}$ was also 3.8 times higher in Holstein dairy cattle $\left(3,267 \mathrm{~g} /\right.$ head/year in Korean beef cattle and 14,719 g/head/year in Holstein dairy cattle). However, the $\mathrm{N}_{2} \mathrm{O}-\mathrm{N}$ per loaded nitrogen into SCF was higher in Korean beef cattle, having 0.2148 and $0.1632 \mathrm{~kg} \mathrm{~N} \mathrm{~N}_{2} \mathrm{O}-\mathrm{N} / \mathrm{kg} \mathrm{N}$ in Korean beef cattle and Holstein dairy cattle, respectively, and those values were 3.07 and 2.33 times higher than that of Intergovernmental Panel on Climate Change (IPCC) 2006 guideline (GL) $(0.07 \mathrm{~kg} \mathrm{~N} 2 \mathrm{O}-\mathrm{N} / \mathrm{kg} \mathrm{N})$.
\end{abstract}

(Key words : Methane, Nitrous oxide, Emission rate, Cowshed floor)

서 론

온실가스 배출자료는 기후변화 협약과 관련된 국제협약 및 국내 저감대책 수립에 없어서는 안되는 중요한 기초자료이다 (Kim 등, $2000 \mathrm{Lim}$ 등, 2011). 산업폐수나 하수처리시설의 경우, 비교적 다 양한 공법과 공정에 대하여 온실가스 배출량을 산정하고 배출계수 를 꾸준히 개발하여 왔으나, 축산부문에서는 이러한 노력이 미미할 뿐 아니라 각 연구에서 통일된 시료채취 및 분석방법이 적용되지 않아 측정값의 정확성을 확인 할 수 없어 배출계수의 비교분석에 한계가 있다. 따라서 실측에 의한 배출량 산정 연구와 시료 채취 방법 및 수집자료, 자료 해석 방법의 구축이 시급한 실정이다(Yun 과 $\mathrm{Yu}, 1998 \mathrm{Kim}$ 등, $2000 \mathrm{Wang}$ 등, 2010). 각국의 온실가스 배출량 자료의 신뢰성을 높이고, 얻어진 결과물에 대해 표준화하여
비교 평가하기 위해 1996년 국제 기후변화협의체인 IPPC에서 GL 을 마련한 이후, 2000, 2006년에 분야별로 부분 개정되었으며, 만 약 국가별로 온실가스 인벤토리 작성방법이 확립되어 있지 않다면 이 $\mathrm{GL}$ 을 따를 것을 권고하고 있다(IPPC, 2006). IPPC GL (2006)에 따라 산출된 전세계 온실가스 배출/흡수 부문별 추이를 살펴보면 (2007년 기준), 에너지 $84.7 \%$, 산업공정 $9.8 \%$, 농 - 축산 $3.0 \%$, 폐기물 $2.5 \%$ 순으로 $(\mathrm{Lim}$ 등, 2011$)$ 다른 분야에 비해 축 산부문에서의 온실가스 발생량이 매우 적은 것으로 보고되고 있다. 그럼에도 불구하고 축산부문 온실가스가 주목 받는 이유는 반추가 축의 장내발효와 분뇨처리 과정에서 발생하는 메탄가스 $(\mathrm{CH} 4)$ 와 아 산화질소가스 $\left(\mathrm{NO}_{2}\right)$ 의 지구온난화 지수가 매우 크기 때문이다 (Snyder 등, 2009; Shen 등, 2011). IPPC에서는 $\mathrm{CH}_{4}$ 과 $\mathrm{N}_{2} \mathrm{O}$ 의 잠재적 지구 온난화 지수가 이산화탄소 $\left(\mathrm{CO}_{2}\right)$ 에 비해 각각 31 ,

* Corresponding author: ChangSix Ra, Dept. of Animal Life System, Kangwon National Uniersity, Chunchon, 200-701, Korea. Tel: (033) 250-8618, Fax: (033) 251-7719, E-mail: changsix@kangwon.ac.kr 
310 배 높다고 보고하고 있다(IPPC, 2001).

우리나라에서의 축산부문 온실가스 배출원에 대한 인벤토리 구축 및 배출계수 산정, 미세먼지 생성과 관련된 연구는 2000년대 초반 부터 진행되어 왔으나 $(\mathrm{Lim}$ 등, 2011), 축종에 따라 사육환경, 사 료, 체중, 분뇨처리 방법 등이 달라 아직까지 축산부문에서의 온실 가스 발생량 등에 관한 기본데이터가 매우 부족한 실정이다. 가축 이 거주하는 축사로부터 발생하는 $\mathrm{CH}_{4}$ 와 $\mathrm{N}_{2} \mathrm{O}$ 가스는 깔짚 두께 와 가축으로부터 배설되는 분뇨량 및 사양환경 등에 따라 변화하기 때문에 정확한 온실가스 측정 및 산정이 어려우며, 특히 가축으로 부터 배설되는 분뇨량 혹은 유기물 및 질소량을 기준으로 온실가스 발생량을 정확하게 산정하기 위해서는 생리적/환경적 여건에 따라 변화하는 일일 분뇨 배설량과 분뇨 성분을 정확히 분석해야 하는데 이는 사실상 현장 실험에서는 불가능하다.

따라서, 본 연구에서는 우리나라 한우와 유우의 깔짚우사에서 발 생되는 온실가스 농도를 측정하여 $\mathrm{CH}_{4}$ 와 $\mathrm{N}_{2} \mathrm{O}$ flux를 정량화하고, 궁극적으로 깔짚우사 바닥에서의 온실가스 배출량 및 배출계수를 산정하고자 깔짚으로 부하되는 분뇨배설량과 분뇨성분을 정확히 산 출/분석할 수 있는 실험실 조건에서의 깔짚두께별 $\mathrm{CH}_{4}$ 와 $\mathrm{N}_{2} \mathrm{O}$ 가 스 발생량을 조사하였다.

\section{재료 및 방법}

\section{1. 실험설계}

한우 및 유우를 대상으로 깔짚우사에서 발생되는 온실가스 농도 를 측정하기 위하여 농림수산식품부에서 제시한 축종별 '친환경축 산 표준모델'의 축사 면적을 참고하여 실험실 시험이 가능한 사이 즈 $(\mathrm{L} \quad 0.63 \mathrm{~m} \times \mathrm{W} \quad 0.41 \mathrm{~m} \times \mathrm{H} \quad 0.22 \mathrm{~m})$ 의 모의축사바닥을 만들어 시험에 사용하였다. 강화 플라스틱을 이용하여 제작된 총 12 개의 모의축사 바닥을 한우, 유우 두 그룹으로 나누고 각각 3 개의 모의 축사 바닥에 깔짚을 $10,15 \mathrm{~cm}$ 두께로 깔아 모든 실험이 3 반복으 로 이루어지도록 하였으며 IPPC GL (2006)의 가축분뇨처리 시 $\mathrm{CH}_{4}$ 과 $\mathrm{N}_{2} \mathrm{O}$ 의 배출계수 제시에서와 동일하게 3개월 (5 7월, 9 11 월, 2 4월)을 기준으로 총 3회 반복 실험하였다.

\section{2. 챔버 제작 및 가스 채취}

지면이나 수면으로 발생되는 기체의 발산량을 측정하는데 널리 이용되고 있는 플럭스 챔버(Flux Chamber)를 Fig. 1과 같이 아크 릴을 이용하여 제작하였다. 제작된 챔버의 부피는총 $36 \mathrm{~L}(0.3 \mathrm{~m} \times$ $0.3 \mathrm{~m} \times 0.4 \mathrm{~m})$ 이었으며, 단면적은 $0.09 \mathrm{~m}^{2}$ 이었다. 챔버는 가스의 흡착 및 방출을 최소화하도록 하였으며, 상부에 소형 fan을 장착하 여 챔버 내부 공기의 균질성을 유지하였고, 유입가스와 배출가스가 혼합되어 충분히 안정되는 체류시간 이후 outline에 테들러 백을 연결하여 시료를 채취하였다. 본 연구에서는 챔버 내부의 가스가 연속적인 흐름상태가 유지될 수 있도록 하기 위해 기체용 정량 펌

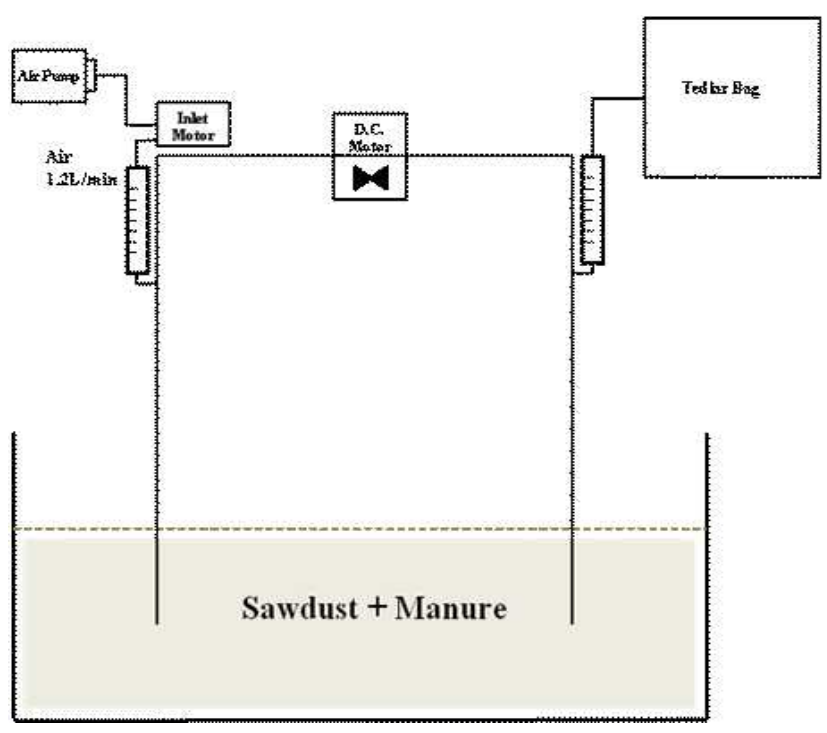

Fig. 1. Schematics of experimental chamber.

프를 이용하여 $1.2 \mathrm{~L} / \mathrm{min}$ 의 유속으로 24 분간 가스를 유입시킨 후 시료를 포집하였다. 가스 포집은 주 2 회 간격으로 오후 2 시에 수행 되었다.

\section{3. 깔짚 및 분뇨 부하량}

우사에서 사용되는 깔짚에는 톱밥, 왕겨 등 여러 가지 재료가 이 용 가능하지만, 현장 조사결과 대부분의 농가에서 톱밥을 사용하고 있는 것으로 파악되어 본 연구에서는 깔짚으로 톱밥을 사용하였다. 기존 연구에서 $5 \mathrm{~cm}$ 의 두께로 이용하는 것이 수분 증발량이 많고 톱밥의 이용효율도 높아지는 것으로 나타나고 있으나, 실제농가에 서는 이보다 두껍게 깔아서 장기간 활용하는 경우가 많고 또한 우 리나라에서는 깔짚 이용 두께 및 주기에 관한 통계가 아직까지 없 는 관계로 본 연구에서는 $10,15 \mathrm{~cm}$ 로 깔고, 이용주기를 3 개월로 하여 바닥깔짚 성상변화와 온실가스 발생량을 조사하였다.

톱밥이 $10,15 \mathrm{~cm}$ 두께로 깔려있는 각각의 모의우사로의 분뇨 부하량은 '친환경 축산 표준모델'의 축종별 사육밀도 (한우 $7 \mathrm{~m}^{2}$ 두, 젖소 $16.5 \mathrm{~m}^{2}$ /두)와 '가축분뇨 발생량 및 주요 성분 재설정' 자료 (Ministry for Food, Agriculture, Forestry and Fisheries, 2008) 의 축종별 일일 분뇨 배설량 자료를 참고하여 한우분뇨 $410 \mathrm{~g} / \mathrm{d}$, 젖소분뇨 $927 \mathrm{~g} / \mathrm{d}$ 로 결정하였다. 실제 우사에서 소에 의해 깔짚과 분뇨가 밟히고 섞이는 효과를 주기 위해 매일 동일한 양의 분뇨를 투입한 후 인위적으로 깔짚과 혼합하였다. Table 1은 시험에 사용 된 젖소 및 한우 분뇨와 깔짚 (톱밥)의 성상 및 축사 단위면적당 질소와 volatile solid(VS)의 평균 부하랑을 나타낸 것이다. 한우 사의 경우 깔짚으로의 평균 질소와 $\mathrm{VS}$ 의 부하율은 각각 5.93 $\mathrm{gN} / \mathrm{m}^{2} / \mathrm{d}, 489.5 \mathrm{gVS} / \mathrm{m}^{2} / \mathrm{d}$ 이었으며 유우사의 경우에는 각각 $11.45 \mathrm{gN} / \mathrm{m}^{2} / \mathrm{d}, 475.57 \mathrm{gVS} / \mathrm{m}^{2} / \mathrm{d}$ 이었다. 
Table 1. Characteristics of manure and sawdust

\begin{tabular}{lccc}
\hline Parameters & Korean beef Cattle & Dairy Cattle & Sawdust \\
\hline \hline Moisture $(\%)$ & $69.15 \pm 0.44$ & $86.74 \pm 0.15$ & $23.29 \pm 0.75$ \\
TS $(\mathrm{g} / \mathrm{kg})$ & $250.48 \pm 8.13$ & $119.37 \pm 1.72$ & $767.06 \pm 0.44$ \\
VS $(\mathrm{g} / \mathrm{kg})$ & $308.45 \pm 4.40$ & $132.55 \pm 1.53$ & $716.43 \pm 0.13$ \\
$\mathrm{TKN}(\mathrm{g} / \mathrm{kg})$ & $3.74 \pm 0.36$ & $3.19 \pm 0.60$ & - \\
VS loading $\left(\mathrm{g} / \mathrm{m}^{2} / \mathrm{d}\right)$ & 489.51 & 475.57 & - \\
$\mathrm{N}$ loading $\left(\mathrm{g} / \mathrm{m}^{2} / \mathrm{d}\right)$ & 5.93 & 11.45 & - \\
\hline
\end{tabular}

4. 시료분석 방법

\section{(1) $\mathrm{CH}_{4}$ 및 $\mathrm{N}_{2} \mathrm{O}$ 분석방법}

테들러 백을 이용하여 포집한 가스 시료는 가능한 24시간 이내 에 분석하였다. $\mathrm{N}_{2} \mathrm{O}$ 와 $\mathrm{CH}_{4}$ 농도 분석은 총 부피가 $60 \mathrm{~mL}$ 인 플라 스틱 재질의 Syringe를 사용하여 일정량 $(50 \mathrm{~mL})$ 을 취하여 직접 주입하였고 전자포획검출기 $(\mathrm{ECD})$ 와 불꽃 이온화 검출기 $(\mathrm{FID})$ 가 장착된 가스크로마토그래피 $(\mathrm{GC}, \operatorname{Varian} \mathrm{Co}$.)로 분석하였다. 분석 에 사용된 컬럼은 Hayesep-Q $(80 / 100,0.5 \mathrm{~m} \times 1 / 8 ” \quad \mathrm{SS})$, Poropak Q (80/100; $2 \mathrm{~m} \times 1 / 8$ " SS), Poropak Q (80/100; 0.5 $\mathrm{m} \times 1 / 8$ ” SS), Poropak Q (80/100; $3 \mathrm{~m} \times 1 / 8$ " SS), Poropak Q $(80 / 100 ; 0.5 \mathrm{~m} \times 1 / 8 " \mathrm{SS})$ 이며, 오븐 온도는 $70^{\circ} \mathrm{C}, \mathrm{FID}$ 와 $\mathrm{ECD}$ 의 디텍터 온도는 각각 $250,300^{\circ} \mathrm{C}$ 로 설정 하였다. Carrier gas는 $\mathrm{N}_{2}$ 를 사용하였고 유속은 $30 \mathrm{~mL} / \mathrm{min}$ 이며, Makeup gas로 FID는 He, $10 \mathrm{~mL} / \mathrm{min} \mathrm{ECD}$ 는 $\mathrm{N}_{2}$ 을 이용하였고 이때 유속은 $10 \mathrm{~mL} / \mathrm{min}$ 로 설정하였다. $\mathrm{CH}_{4}$ 와 $\mathrm{N}_{2} \mathrm{O}$ 의 Calibrations gas standards (Research Institute of $\mathrm{Gas}$ Analytical Science)는 $\mathrm{CH}_{4}(2.1 \mu \mathrm{mol} / \mathrm{mol})$ 과 $\mathrm{N}_{2} \mathrm{O}(1.0 \mu \mathrm{mol} / \mathrm{mol})$ 를 사용하였으며, $\mathrm{CH}_{4}$ 와 $\mathrm{N}_{2} \mathrm{O}$ 의 반응 시간은 1.15 와 4.4 분이었다. 분석된 가스 샘플의 반응계수 값은 $\mathrm{ppm}$ 으로 계산하여 나타냈다.

(2) 시험에 사용된 분뇨 채취 및 성분 분석 방법 시험에 사용된 한우 및 유우 분뇨는 중부지방에 위치한 농가로부 터 채취한 후 매일 깔짚에 혼합할 양만큼씩 용기에 분주하여 -20 ${ }^{\circ} \mathrm{C}$ 냉동고에 보관하면서 깔짚에 혼합하기 직전에 용해시켜 사용하 였다. 분뇨와 톱밥 및 분뇨 깔짚 혼합물 샘플의 총고형물 (Total Solid, TS)과 VS의 함량은 Standard Method (APHA: American Public Health Association, 1998)에 준하여 분석하였으며 시료의 입자 크기에 따른 분석오차를 방지하기 위하여 모든 시료를 분석 전에 grinder로 분쇄한 후 분석하였다.

깔짚과 분뇨 혼합물 내 $\mathrm{NOx}-\mathrm{N}$ 의 농도는 분쇄된 시료 $2 \mathrm{~g}$ 을 증 류수 $(\mathrm{pH} 7.0) 100 \mathrm{ml}$ 에 넣어 50 배 $(\mathrm{w} / \mathrm{v})$ 희석한 다음 4시간 교반 하고 filter paper(Watman No. 1541.110)로 여과한 후 자동수질 분석기 (Zellweger: LACHT, QuikChem 8000)를 사용하여 분석 하였다. Total Kieldahl Nitrogen (TKN)은 분쇄된 시료를 block digestor (BD46, LACHAT)를 이용하여 소화시킨 다음 자동수질
분석기를 이용하여 분석하였다. 모든 시료의 수분함량은 $105^{\circ} \mathrm{C}$ 에서 24시간 건조한 후 측정하였다.

\section{5. $\mathrm{CH}_{4}$ 및 $\mathrm{N}_{2} \mathrm{O}$ 배출농도 계산}

온실가스 배출량을 산정하기 위해서 채취한 가스의 측정 결과를 외부 공기의 측정값에 보정하고, 측정된 $\mathrm{CH}_{4}$ 와 $\mathrm{N}_{2} \mathrm{O}$ 가스 농도는 표면발산량으로 환산하였으며, 시료채취지점의 $\mathrm{CH}_{4}$ 와 $\mathrm{N}_{2} \mathrm{O}$ 유출속 도 계산식은 다음과 같다 $(\mathrm{Oh}$ 등, 2009).

$$
E_{i}=\frac{C_{i} \times M_{w} \times P \times F_{r}}{R \times \mathrm{T} \times \mathrm{A}}
$$

$E_{i}$ : $\mathrm{CH}_{4}, \mathrm{~N}_{2} \mathrm{O}$ emission rate of component $\mathrm{I}\left(\mu \mathrm{g} / \mathrm{m}^{2} \cdot \min \right)$

$C_{i}$ : $\mathrm{CH}_{4}, \mathrm{~N}_{2} \mathrm{O}$ concentration of component I (ppmv)

$M_{w}: \mathrm{CH}_{4}, \mathrm{~N}_{2} \mathrm{O}$ molar mass (16 g/mole, $44 \mathrm{~g} /$ mole)

$P$ : internal pressure in chamber (atm)

$F_{r}$ : gas flow rate within chamber $(\mathrm{L} / \mathrm{min})$

$R$ : gas constant $(0.082 \mathrm{~atm} \cdot \mathrm{L} / \mathrm{mole} \cdot \mathrm{K})$

$T$ : average temperature in the chamber $(\mathrm{k})$

$A$ : surface area enclosed by of the chamber $\left(\mathrm{m}^{2}\right)$

\section{6. 통계분석방법}

본 실험에서 얻어진 데이터의 통계분석은 Excel program (Microsoft Office, 2007)을 이용하였으며 일원배치분산분석법 (One Way ANOVA)으로 95\% 신뢰수준에서 유의성을 검증하 였다.

\section{결과 및 고찰}

\section{1. 깔짚 성상 변화}

모의축사바닥에 톱밥을 $10,15 \mathrm{~cm}$ 높이로 깔고 한우와 유우의 분뇨를 매일 투입/혼합하면서 시간 경과에 따른 수분함량과 VS 함 량 변화를 관찰하였다(Fig. 2). 수분함량의 경우, 실험 초기에는 


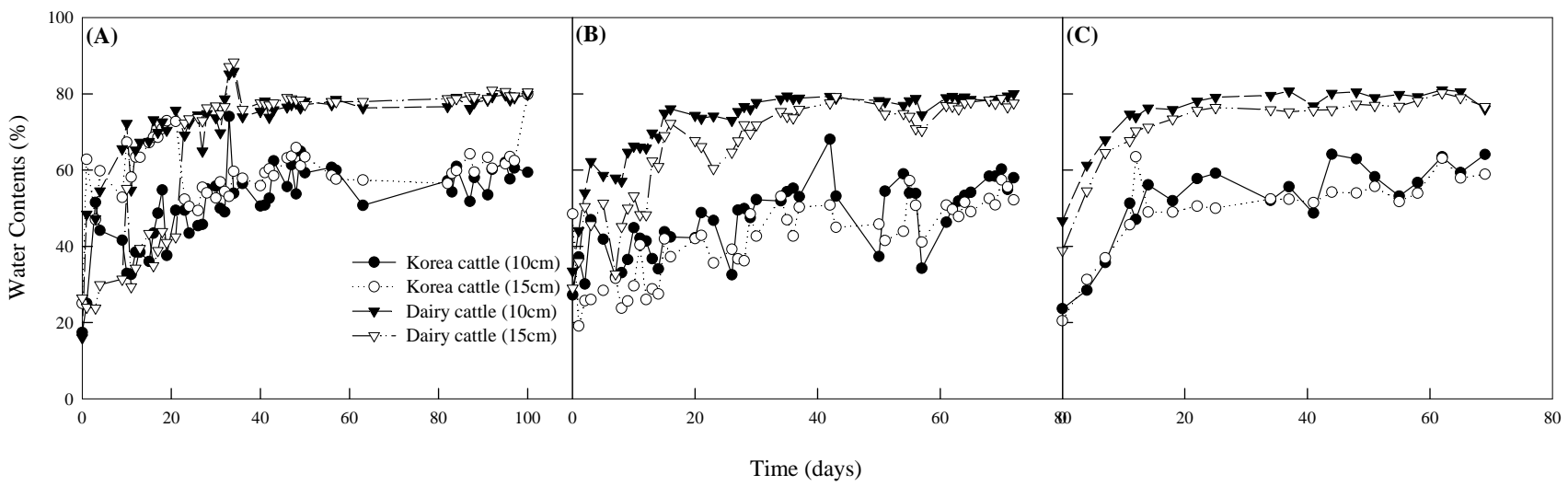

Fig. 2. Monitoring of water contents in bedding material.

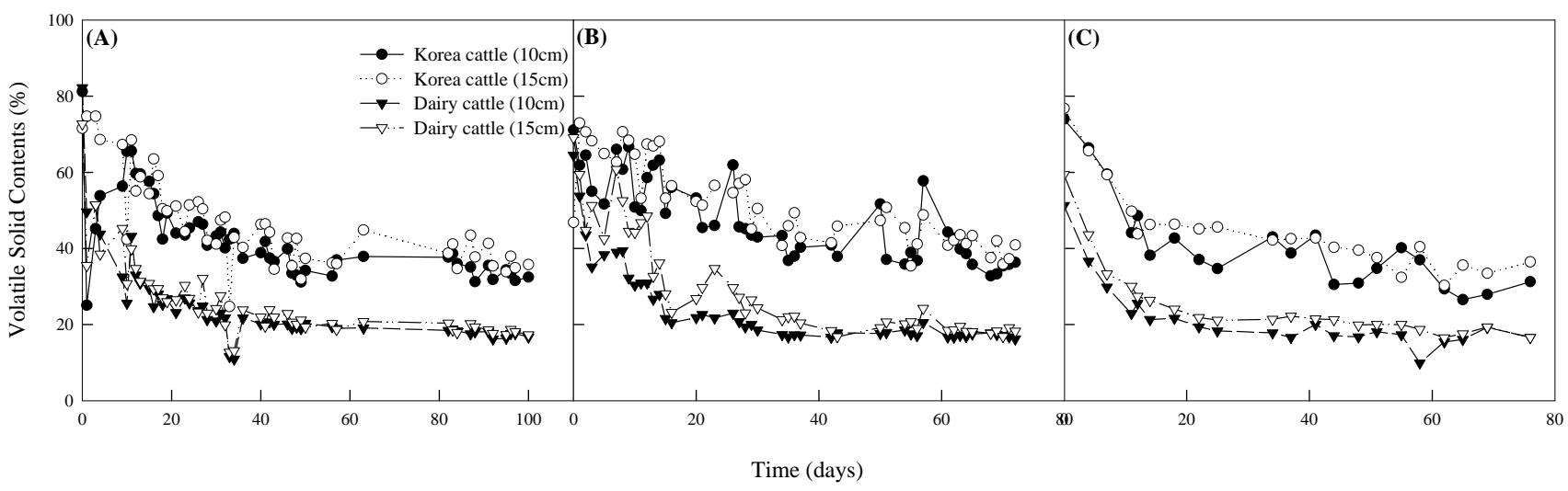

Fig. 3. Monitoring of volatile solid content in bedding material.

약 $20 \%$ 였으나 실험 종료시점에서는 한우사 $60 \%$, 유우사에 $80 \%$ 수준으로 증가함을 관찰 할 수 있었다. 깔짚 두께별 수분함량을 살 펴보았을 때 $10 \mathrm{~cm}$ 보다는 $15 \mathrm{~cm}$ 두께에서 다소 낮았으나 그 차 이가 크지 않았으며 깔짚두께와 상관없이 30일까지 수분함량이 빠 르게 증가하다가 그 후 점차 둔화되면서 한우의 경우 $50 \sim 6 \%$, 유 우의 경우 약 $80 \%$ 의 수준을 유지함을 알 수 있었다. 한우 및 유우 분뇨의 수분함량이 각각 $69 \%$ 와 $87 \%$ 임을 고려할 때 유우의 경우 에는 계절에 관계없이 약 40 일 이후에 한우의 경우에는 5 7월 및 2 4월에는 약 50 60일, 9 11월에는 약 70일 이후에 깔짚내 수분 함량이 서서히 포화상태에 도달함을 의미한다 할 수 있다.

휘발성 고형물질 함량의 경우, 한우사와 유우사 모두 실험 초기 에는 70 80\%였다가, 시간이 경과함에 따라 감소하는 경향을 보 였다(Fig. 3). 한우와 유우를 비교할 때 유우의 경우에는 약 20 30일 이후에 VS 함량이 $20 \%$ 수준 이하로 감소한 반면, 한우 의 경우에는 약 60 일 이후에 $35 \%$ 수준 이하로 감소하는 것으로 나타나 VS 함량의 감소율은 한우에 비해 유우가 높음을 알 수 있 었다. 수분함량과 마찬가지로 VS 함량의 변화는 깔짚 높이보다는 축종에 따라 차이를 보였는데 이는 온도가 동일한 조건에서 한우사 에 비해 유우사에 유입된 분뇨 내 수분함량이 높고 또한 유우의 분 뇨 배설량이 단위면적당 2.3 배 많아 유우사 바닥 깔짚물질의 수분
함량이 유기물의 분해가 활발하게 일어나는 $65 \%$ 수준으로 빠르게 증가하였기 때문으로 판단된다.

\section{2. $\mathrm{CH}_{4}$ 와 $\mathrm{N}_{2} \mathrm{O}$ 발생량 및 가스 배출 특성}

Fig. 4는 시간이 경과함에 따라 발생되는 메탄가스의 농도 변화 를 나타낸 것이다. 5 7월 실험군에서 한우사와 유우사 모두 80일 이후에 높은 농도의 $\mathrm{CH}_{4}$ 가 발생하면서(Fig. $4 \mathrm{~A}$ ) 유우사에서는 깔 짚 두께 $10,15 \mathrm{~cm}$ 에서 각각 최고 $443,633 \mathrm{mg} / \mathrm{m}^{2} / \mathrm{d}$ 까지 발생한 것으로 분석되었다. 이때 메탄가스의 배출량이 높게 나타난 것은 깔짚 물질이 시간이 경과함에 따라 점차 분해되면서 통기성이 낮아 지고 계속되는 분뇨혼합으로 수분함량이 $80 \%$ 이상으로 높아짐에 따라 혐기적 상태가 형성되었기 때문인 것으로 판단된다. 그러나 9 11월 및 2 4월에 수행된 시험구에서는 5 7월 시험구에서와 같 은 특이적인 경향이 관찰되지 않았다(Fig. 4 B,C).

$\mathrm{N}_{2} \mathrm{O}$ 의 경우(Fig. 5), 5 7월에는 모든 실험구에서 20일 이후 급 격히 증가했다가 50일경부터 감소하는 경향을 보였으나(Fig. 5A), 9 11월과 2 4월 시험에서는 일정한 경향이 관찰되지 않았다(Fig. $5 \mathrm{~B}, \mathrm{C}) . \mathrm{N}_{2} \mathrm{O}$ 는 일반적으로 호기적 질산화과정에 의해 생성된 $\mathrm{NO}_{3}$ 와 $\mathrm{NO}_{2}$ 가 탈질 과정에서 $\mathrm{N}_{2}$ 가스로 전환되는 과정 중에 생성되는 

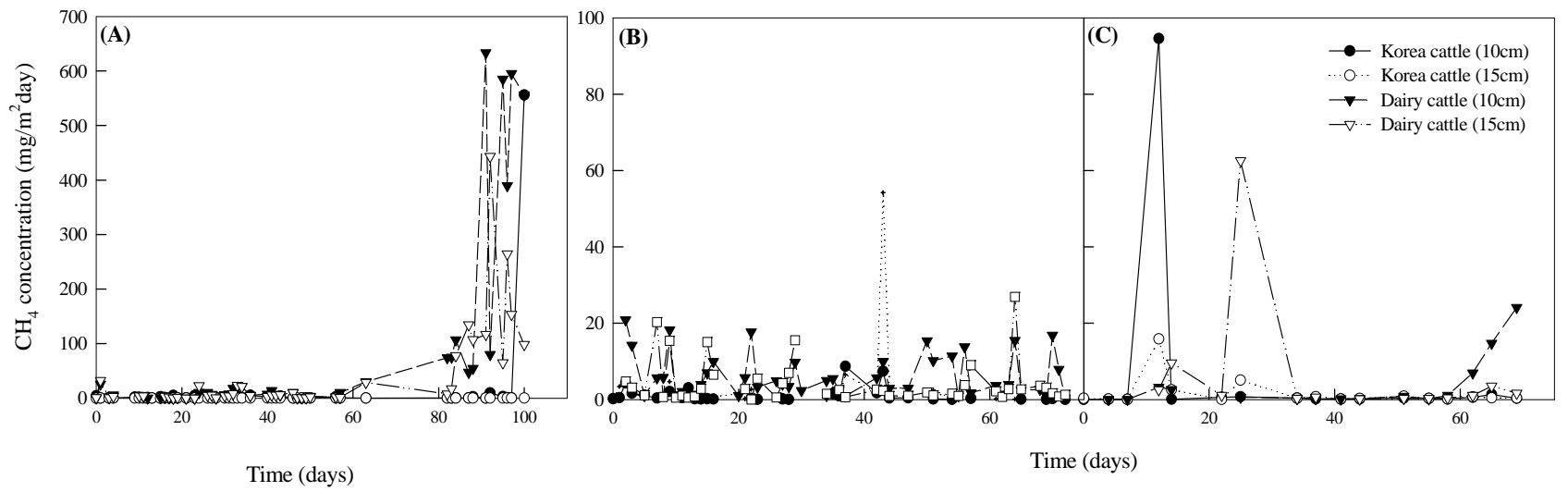

Fig. 4. Emission of $\mathrm{CH}_{4}$ from bedding material.

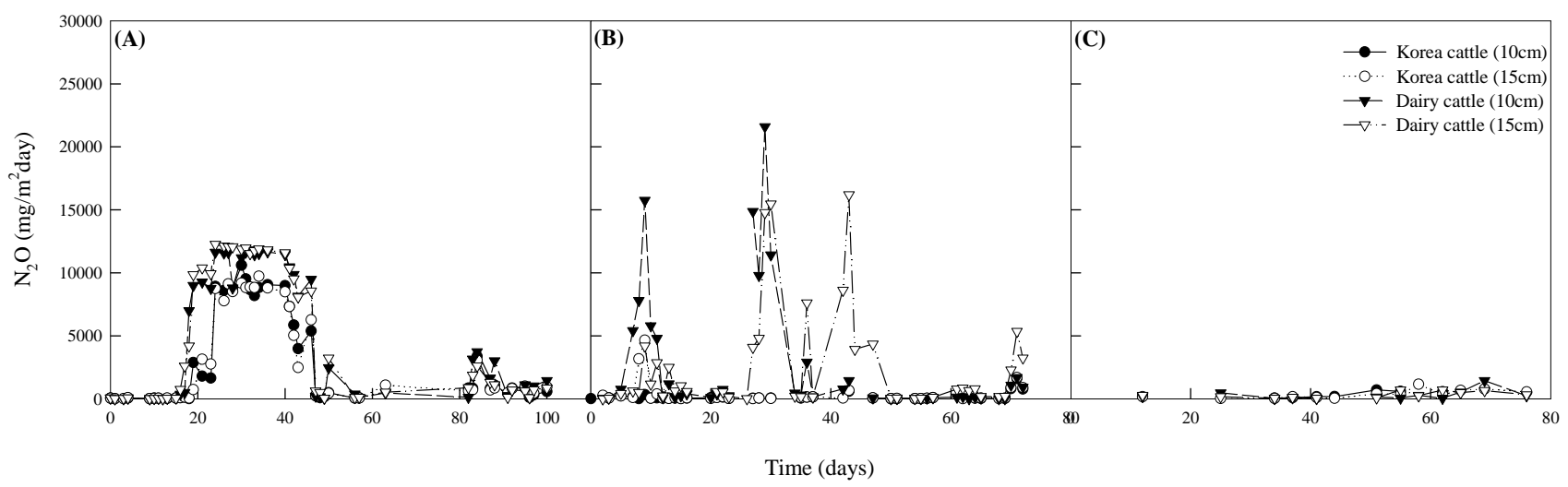

Fig. 5. Emission of $\mathrm{N}_{2} \mathrm{O}$ from bedding material.

데 정확한 생성 이유에 대해서는 정확히 알려져 있지 않다. 그러나 문헌 등에 의하면 $\mathrm{N}_{2} \mathrm{O}$ 배출에 영향을 미치는 인자로는 산소농도, 온도, $\mathrm{pH}$, 암모니아 농도 $(500 \mathrm{mg} / \mathrm{L})$, 아질산 축적 등이 있다 $(\mathrm{Lim}$ 등 2011). 한우사에 비해 유우사에서 $\mathrm{N}_{2} \mathrm{O}$ 배출이 많은 이유는 유 우의 분뇨배설량과 분내 수분함량이 한우보다 높기 때문인 것으로 판단되며, 수분함유량이 높아질수록 건조한 상태에서 활동이 제한 되었던 미생물의 활동이 충분한 수분 조건하에서 활성됨에 따라 질 화/탈질화 과정의 진행이 촉진되었기 때문으로 판단된다 $(\mathrm{Su}$ 등, 2003). 또한 수분함량이 증가함에 의해서 미생물 활동에 필요한 기 질성분들이 분뇨와 깔짚 사이에 용해됨에 따라 미생물의 활동을 증 가시키게 되고 결과적으로 대사생성물인 가스생성을 촉진시킨 것으 로 판단된다. 또한 지속적인 수분량 증가는 공극을 감소시켜 기체 확산과 이동에 제한을 줌은 물론 혐기상태를 보다 가속화시켜 깔짚 내 질소성분들은 탈질화 과정의 $\mathrm{N}_{2}$ 로 전환되게 된다(Amon 등, 2006; Gupta 등, 2007). 토양의 경우 함수량이 $60 \%$ 에서 질산화과 정과 탈질화과정이 서로 공존하여 최대 $\mathrm{N}_{2} \mathrm{O}$ 배출을 보이며, 위와 같은 조건에서 온도가 증가되면 탈질화 과정을 촉진시킬 수 있기 때문에 $\mathrm{N}_{2} \mathrm{O}$ 배출을 가속화 시킬 수 있는 것으로 알려지고 있다 (Kim 등, 2003).

깔짚내 NOX-N의 농도 변화를 보면(Fig. 6), 시간이 경과함에
따라 한우사 깔짚에서는 농도가 증가하는 반면 유우사 깔짚에서는 큰 변화가 관찰되지 않았는데 이는 유우 분뇨의 수분 함량이 높고 또한 배설량이 많아 깔짚의 수분함량이 한우에 비해 비교적 빠른 시기에 높게( $80 \%$ 이상) 증가함에 따라 깔짚내에 부분적인 혐기 혹은 무산소 상태가 형성되고 그 결과 질산화과정 중에 생성된 $\mathrm{NO}_{2}$ 및 $\mathrm{NO}_{3}$ 가 $\mathrm{N}_{2} \mathrm{O}$ 혹은 $\mathrm{N}_{2}$ 가스로 전환되어 배출되었기 때문으 로 판단된다(Yamulki 등, 2006; Gupta 등, 2007). Table 2는 실 험에서 얻은 결과값을 이용하여 축사단위면적 당 일일 온실가스 발 생량을 산정한 것이다. 단위면적당 $\mathrm{CH}_{4}$ 발생량은 한우에 비해 유 우에서 높은데 Kaparaju (2011) 등에 의하면 이는 유우의 분뇨 내 유기물 함량이 높고 수분 함량이 높기 때문으로 실제 $\mathrm{CH}_{4}$ 발생량 이 다른 축종(육우 혹은 돈분, 계분)에 비해 1.5 2배 가량 많이 발생되는 것으로 보고되고 있다. Sa (2010)와 Shen(2011) 등은 또한 계분을 대상으로 공기 유입량에 따른 메탄가스 방출량을 조사 한 결과, 메탄가스 발생량은 유입되는 유기물 농도에 절대적으로 영향을 받으며, 공기량이 적으면 적을수록 혐기적 상태로 되면서 메탄가스 발생량이 많다고 보고하였다. 깔짚 두께별 $\mathrm{CH}_{4}$ 발생량을 보면 한우 및 유우 모두에서 깔짚이 두꺼운 경우 발생량이 적은 경 향을 보였으나 통계분석 결과 2 4월 실험을 제외하곤 유의적인 차 이를 보이지 않았으며 $(\mathrm{p}<0.05), \mathrm{N}_{2} \mathrm{O}$ 의 경우에도 깔짚두께에 따른 


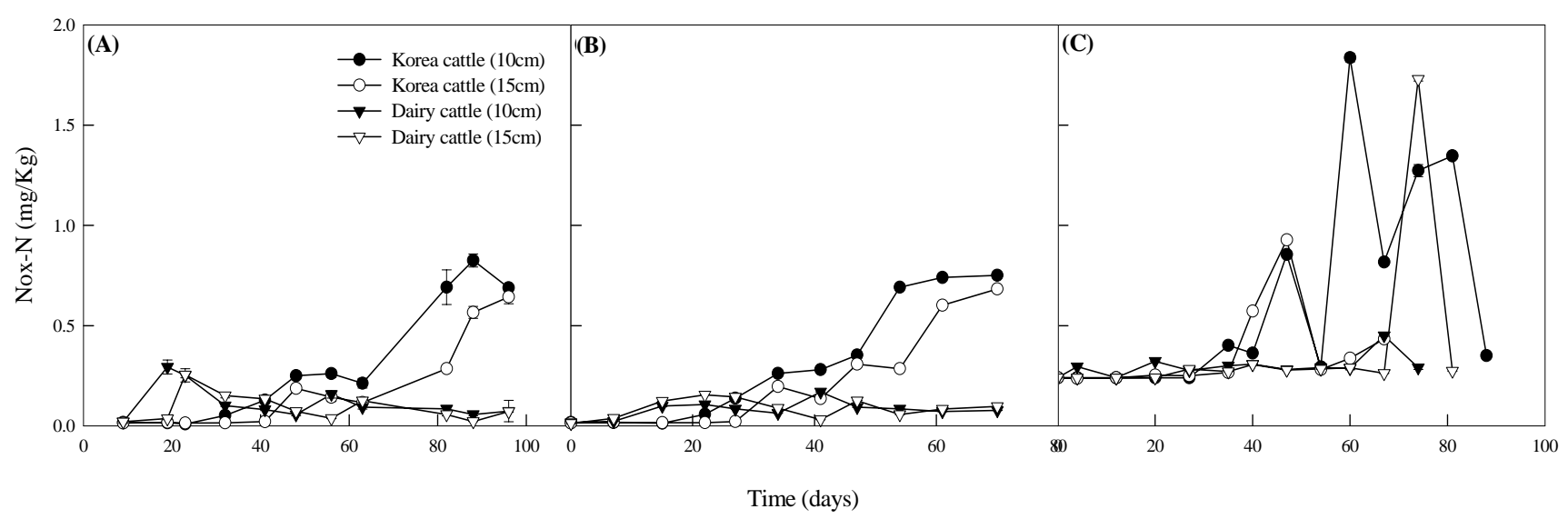

Fig. 6. Monitoring of NOx-N in bedding material.

Table 2. Greenhouse gas emissions from cowshed floor with sawdust

(a) Methane gas $\left(\mathrm{CH}_{4}\right.$ concentration: $\left.\mathrm{mg} / \mathrm{m}^{2} / \mathrm{d}\right)$

\begin{tabular}{cccccc}
\hline & Sawdust thickness $(\mathrm{cm})$ & $1^{*}$ & $2^{* *}$ & $3^{* * *}$ & AVG \\
\hline \hline \multirow{2}{*}{ Korean beef cattle } & 10 & $1.534^{\mathrm{a}}$ & $0.325^{\mathrm{a}}$ & $8.700^{\mathrm{a}}$ & $3.520^{\mathrm{a}}$ \\
& 15 & $1.057^{\mathrm{a}}$ & $0.914^{\mathrm{a}}$ & $4.715^{\mathrm{b}}$ & $2.229^{\mathrm{a}}$ \\
\hline \multirow{2}{*}{ Dairy Cattle } & & & & 2.875 \\
& 10 & $62.517^{\mathrm{c}}$ & $2.286^{\mathrm{c}}$ & $28.437^{\mathrm{c}}$ & $31.081^{\mathrm{c}}$ \\
\hline & 15 & $26.174^{\mathrm{c}}$ & $1.518^{\mathrm{c}}$ & $6.491^{\mathrm{d}}$ & $12.238^{\mathrm{c}}$ \\
\hline
\end{tabular}

(b) Nitrous Oxide gas $\left(\mathrm{N}_{2} \mathrm{O}\right.$ concentration: $\left.\mathrm{mg} / \mathrm{m}^{2} / \mathrm{d}\right)$

\begin{tabular}{cccccc}
\hline & & $1^{*}$ & $2^{* *}$ & $3^{* * *}$ & AVG \\
\hline \hline \multirow{2}{*}{ Korean beef cattle } & 10 & $2,936.256^{\mathrm{a}}$ & $57.510^{\mathrm{a}}$ & $1,228.082^{\mathrm{a}}$ & $1,407.283^{\mathrm{a}}$ \\
& 15 & $2,889.122^{\mathrm{a}}$ & $134.611^{\mathrm{a}}$ & $397.898^{\mathrm{a}}$ & $1,140.544^{\mathrm{a}}$ \\
\hline \multirow{2}{*}{ Dairy Cattle } & & & & $\mathbf{1 , 2 7 3 . 9 1 3}$ \\
& 10 & $3,859.720^{\mathrm{c}}$ & $934.945^{\mathrm{c}}$ & $286.484^{\mathrm{c}}$ & $1,693.717^{\mathrm{c}}$ \\
& 15 & $3,928.421^{\mathrm{c}}$ & $926.040^{\mathrm{c}}$ & $2,326.166^{\mathrm{d}}$ & $2,393.543^{\mathrm{c}}$ \\
\hline
\end{tabular}

*1: May July, 2011, **2: September November, 2011, ***3: February April, 2012.

${ }^{a, b, c, d}$ Means in the same column of each animal category with the same superscript are statistically insignificant at $5 \%$ level of significance.

차이가 관찰되지 않았다. 한우사의 경우 깔짚으로부터의 $\mathrm{CH}_{4}$ 평균 배출량은 깔짚두께 $10 \mathrm{~cm}$ 에서 $3.520 \mathrm{mg} / \mathrm{m}^{2} / \mathrm{d}$, 깔짚두께 $15 \mathrm{~cm}$ 에 서 $2.229 \mathrm{mg} / \mathrm{m}_{2} / \mathrm{d}$ 이었으며, $\mathrm{N}_{2} \mathrm{O}$ 는 깔짚두께 $10,15 \mathrm{~cm}$ 에서 각 각 $1,407.3,1,140.5 \mathrm{mg} / \mathrm{m}^{2} / \mathrm{d}$ 발생하였다. 유우사의 경우에는 깔짚 으로부터의 평균 $\mathrm{CH}_{4}$ 배출량은 깔짚두께 $10,15 \mathrm{~cm}$ 에서 각각 36.869 과 $14.517 \mathrm{mg} / \mathrm{m}^{2} / \mathrm{d}$ 이었으며 $\mathrm{N}_{2} \mathrm{O}$ 의 평균 발생량은 각각 2,009.2와 2,839.3 mg/m²/d 이었다.

깔짚으로부터의 $\mathrm{CH}_{4}$ 와 $\mathrm{N}_{2} \mathrm{O}$ 발생랑을 비교할 때 한우의 경우
$\mathrm{N}_{2} \mathrm{O}$ 발생량이 $\mathrm{CH}_{4}$ 에 비해 무려 444배 정도, 유우의 경우에는 94 배 정도 많음을 알 수 있었으며 한우와 젖소를 비교할 때 단위면적 당 온실가스 발생량은 한우에 비해 젖소가 $\mathrm{CH}_{4}$ 는 7.5 배, $\mathrm{N}_{2} \mathrm{O}$ 는 1.2 배 많음을 알 수 있었다.

\section{3. $\mathrm{CH}_{4}$ 와 $\mathrm{N}_{2} \mathrm{O}$ 배출계수 산정}

Table 3은 본 연구의 결과를 토대로 친환경축사규정에 준하여 
Table 3. Greenhouse gas emissions rate from cowshed floor with sawdust

\begin{tabular}{|c|c|c|c|c|c|}
\hline $\begin{array}{l}\text { Animal species / } \\
\text { category }\end{array}$ & $\begin{array}{l}\text { Sawdust } \\
\quad(\mathrm{cm})\end{array}$ & Season & $\begin{array}{c}\mathrm{CH}_{4} \\
(\mathrm{~g} / \mathrm{head} / \mathrm{yr})\end{array}$ & $\begin{array}{c}\mathrm{N}_{2} \mathrm{O} \\
(\mathrm{g} / \mathrm{head} / \mathrm{yr})\end{array}$ & $\begin{array}{c}\mathrm{N}_{2} \mathrm{O} \\
\left(\mathrm{kg} \mathrm{N}_{2} \mathrm{O}^{-} \mathrm{N} / \mathrm{kg} \mathrm{N}\right)\end{array}$ \\
\hline \multirow{9}{*}{ Korean beef cattle } & \multirow{4}{*}{10} & $1^{*}$ & 3.919 & $7,502.134$ & 0.4952 \\
\hline & & $2 * *$ & 0.866 & 154.899 & 0.0097 \\
\hline & & $3 * * *$ & 22.229 & $3,137.749$ & 0.2071 \\
\hline & & AVG & 9.004 & $3,598.260$ & 0.2373 \\
\hline & \multirow{4}{*}{15} & $1 *$ & 2.700 & 7,3817 & 0.4872 \\
\hline & & $2^{* *}$ & 2.397 & 336.173 & 0.0227 \\
\hline & & $3 * * *$ & 12.047 & $1,059.163$ & 0.0671 \\
\hline & & AVG & 5.715 & $2,935.680$ & 0.1923 \\
\hline & AVG & & 7.360 & $3,266.970$ & 0.2148 \\
\hline \multirow{9}{*}{ Dairy cattle } & \multirow{4}{*}{10} & $1 *$ & 376.508 & $23,245.164$ & 0.3371 \\
\hline & & $2^{* *}$ & 13.767 & $5,630.706$ & 0.0817 \\
\hline & & $3 * * *$ & 171.262 & $1,725.350$ & 0.0250 \\
\hline & & AVG & 187.185 & $10,200.411$ & 0.1479 \\
\hline & \multirow{4}{*}{15} & $1 *$ & 157.633 & $23,658.915$ & 0.3431 \\
\hline & & $2 * *$ & 9.142 & $5,577.076$ & 0.0809 \\
\hline & & $3 * * *$ & 39.092 & $14,009.335$ & 0.2032 \\
\hline & & AVG & 73.703 & $14,415.113$ & 0.1785 \\
\hline & \multicolumn{2}{|l|}{ AVG } & 130.357 & $12,307.756$ & 0.1632 \\
\hline
\end{tabular}

* 1: May July, 2011, ** 2: September November, 2011, ***3: February April, 2012.

한우와 젖소를 사육할 때 깔짚으로부터 연간 배출되는 $\mathrm{CH}_{4}$ 및 $\mathrm{N}_{2} \mathrm{O}$ 배출량을 산정한 결과를 요약한 것이다. 깔짚두께 $10,15 \mathrm{~cm}$ 평균 $\mathrm{CH}_{4}$ 발생량은 한우 $7.4 \mathrm{~g} / \mathrm{head} / \mathrm{year}$, 젖소 $130.4 \mathrm{~g} / \mathrm{head} / \mathrm{year}$ 로 젖소가 17.7배 많았으며, IPCC $2006 \mathrm{GL}$ 의 깔짚에서 발생되는 $\mathrm{CH}_{4}$ 배출계수는 현재 국가 배출량 산정 시 북아메리카 값을 적용 하고 있으나 축종별로 구분만 하고 있을 뿐 분뇨처리 혹은 관리에 방법에 대한 고려가 없어 본 연구에서 얻어진 배출계수와 직접적으 로 비교할 수는 없을 것으로 판단된다. 깔짚으로부터의 연간 $\mathrm{N}_{2} \mathrm{O}$ 발생량은 한우 $3,267 \mathrm{~g} / \mathrm{head} / \mathrm{year}$, 젖소 $14,719 \mathrm{~g} / \mathrm{head} / \mathrm{year}$ 로 젖 소가 한우에 비해 약 4.5 배 많음을 알 수 있었으며 깔짚으로부터 발생하는 온실가스는 $\mathrm{CH}_{4}$ 보다 $\mathrm{N}_{2} \mathrm{O}$ 가 많음을 알 수 있었다. IPCC $2006 \mathrm{GL}$ 의 깔짚에서 발생되는 직접적 $\mathrm{N}_{2} \mathrm{O}$ 배출계수는 깔 짚 혼합이 없을 경우 $0.01 \mathrm{~kg} \mathrm{~N} 2 \mathrm{O}-\mathrm{N} / \mathrm{kg} \mathrm{N}$, 혼합을 해주는 경우 $0.07 \mathrm{~kg} \mathrm{~N} \mathrm{~N}_{2} \mathrm{O}-\mathrm{N} / \mathrm{kg} \mathrm{N}$ 로 제시하고 있는데 본 연구에서는 한우 $0.2148 \mathrm{~kg} \mathrm{~N} \mathrm{~N}_{2} \mathrm{O}-\mathrm{N} / \mathrm{kg} \mathrm{N}$, 젖소 $0.1632 \mathrm{~kg} \mathrm{~N} 2 \mathrm{O}-\mathrm{N} / \mathrm{kg}$ N으로 깔짚 혼합이 있을 경우의 IPCC값 $0.07 \mathrm{~kg} \mathrm{~N} \mathrm{~N}_{2} \mathrm{O}-\mathrm{N} / \mathrm{kg} \mathrm{N}$ 과 비교할 때 한우는 약 3.07 배 젖소는 약 2.33 배 정도 높은 것으로 나타났다. 사실 IPCC $2006 \mathrm{GL}$ 에 수록되어있는 $\mathrm{N}_{2} \mathrm{O}$ 배출계수는 축종에 따 른 구별 없이 깔짚에서의 발생 정도만을 대략적으로 제시하고 있 다.

\section{요 약}

우사바닥깔짚으로부터의 온실가스 배출량을 산정하기 위해 깔짚 으로의 분뇨부하량을 정확히 조절할 수 있는 모의우사바닥에서의 깔짚두께별 $\mathrm{CH}_{4}$ 와 $\mathrm{N}_{2} \mathrm{O}$ 가스 발생량을 조사하였다. 톱밥이 10 , $15 \mathrm{~cm}$ 높이로 깔린 $0.2583 \mathrm{~m}^{2}(\mathrm{~L} 0.63 \mathrm{~m} \times \mathrm{W} 0.41 \mathrm{~m})$ 크기의 우 사바닥으로의 한우와 젖소의 분뇨부하는 친환경 축사표준모델의 축 사면적과 축종별 일일 분뇨배설량 자료를 기준으로 한우는 1.586 $\mathrm{kg} / \mathrm{m}^{2} / \mathrm{d}$, 젖소는 $3.588 \mathrm{~kg} / \mathrm{m}^{2} / \mathrm{d}$ 로 정하고 24 시간 주기로 분뇨를 투입/혼합하면서 깔짚으로부터 발생하는 온실가스 발생량을 조사하 였다. 총 12 개의 모의우사바닥을 이용하여 모든 실험은 3 반복으로 3 회에 걸쳐 수행되었다(5 7월, 9 11월, 2 4월). 그 결과 단위면적 당 $\mathrm{CH}_{4}$ 발생량은 한우, 젖소 모두에서 깔짚이 두꺼운 경우 적게 발생하는 경향을 보였으나 통계적으로 유의적인 차이가 없었으며 $(\mathrm{p}<0.05), \mathrm{N}_{2} \mathrm{O}$ 발생량의 경우에도 깔짚두께에 따른 차이가 없는 것으로 나타났다. 한우와 젖소를 비교할 때 단위면적당 온실가스 발생량은 젖소가 $\mathrm{CH}_{4}$ 는 약 7.5 배, $\mathrm{N}_{2} \mathrm{O}$ 는 약 1.2 배 많았으며 연간 배출되는 $\mathrm{CH}_{4}$ 는 한우 $7.4 \mathrm{~g} / \mathrm{head} / \mathrm{year}$, 젖소 $130.4 \mathrm{~g} / \mathrm{head} / \mathrm{year}$ 로 젖소가 한우에 비해 21 배 높은 것으로 나타났다. 또한 $\mathrm{N}_{2} \mathrm{O}$ 는 한 우 $3,267 \mathrm{~g} / \mathrm{head} / \mathrm{year}$, 젖소 $14,719 \mathrm{~g} / \mathrm{head} / \mathrm{year}$ 로 젖소가 약 4.5 
배 많았으나 배설된 $\mathrm{N}$ 대비 $\mathrm{N}_{2} \mathrm{O}-\mathrm{N}$ 은 한우 $0.2148 \mathrm{~kg} \mathrm{~N} \mathrm{~N}_{2} \mathrm{O}-\mathrm{N} / \mathrm{kg}$ $\mathrm{N}$, 젖소 $0.1632 \mathrm{~kg} \mathrm{~N} \mathrm{~N}_{2} \mathrm{O}-\mathrm{N} / \mathrm{kg}$ 으로 오히려 한우가 높았으며 IPCC 2006 GL값 $0.07 \mathrm{~kg} \mathrm{~N} \mathrm{~N}_{2} \mathrm{O}-\mathrm{N} / \mathrm{kg} \mathrm{N}$ 과 비교시 한우는 약 3.07 배, 젖소는 약 2.33 배 높은 것으로 나타났다.

(주제어: 메탄, 아산화질소, 배출율, 우사바닥)

$$
\text { 사 사 }
$$

본 연구는 농촌진흥청 “기후변화대응 미래농업기술 개발” 연구비 지원으로 수행되었으며 이에 감사드립니다.

\section{인 용 문 헌}

Amon, M., Kryvoruchko, V., Amon, T. and Zechmeister-Boltenstern, S. 2006. Methane, nitrous oxide and ammonia emissions during storage and after application of dairy cattle slurry and influence of slurry treatment. Agric. Ecosyst. Environ. 112:153-162.

APHA. 1998. Standard methods for the examination of water and wastewater. WPCF.

Gupta, P. K., Jha, A. K., Koul, S., Sharma, P., Pradhan, V., Gupta, V., Sharma, C. and Singh, N. 2007. Methane and nitrous oxide emission from bovine manure management practices in India. Environ. Pollut. 146:219-224.

IPCC, 1996. Climate change 1995: the science of climate change. Intergovernmental Panel on Climate Change, Cambridge University Press, Cambridge, U.K.

IPCC. 2001. Climate change 2001: the scientific basis. http:/ /www.grida.no/climate/ipcc_tar/wgl/index.htm Accessed Apr. 11, 2007.

IPCC. 2006. Intergovernmental Panel on Climate Change Guidelines for National Greenhouse Gas Inventories. http://www.ipcc-nggip. iges.or.jp/public/2006gl/pdf/4_Volume4/V4_11_Ch1_ $\mathrm{N}_{2} \mathrm{O} \& \mathrm{CO}_{2}$. pdf. 14 Apr. 2008.

Kaparaju. P. and Rintala J. 2011. Mitigation of greenhouse gas emissions by adopting anaerobic digestion technology on dairy, sow, and pig farms in Finland. Renewable energy. 36:31-41

Kim, D. S. and Oh, J. M. 2003. $\mathrm{N}_{2} \mathrm{O}$ emissions from agricultural soils and their characteristics. J. Kor. Atmo. Environ. 19:529-540.

Kim, D. S., Jang, Y. K. and Jeuon, E. C. 2000. Surface flux measurements of methane from landfills by closed chamber technique and its validation, $\mathrm{J}$ of Kor. Atmo. Environ. 16: 499-509.

Lim, B. R., Cho, K. J., Jung, E. H., Yang J. K. and Lee, S. G. 2011. Estimation of greenhouse gas emission from livestock wastewater treatment plants. J. Kor. Waste management. 28: 175-183.

Ministry for food, agriculture, forestry and fisheries. 2008. Ecofriendly Agricultural Standard Model. 11-1541000-000005-01. KOREA. Pp. 44-45.

Oh, W. K., Chu, Y. Y, Juong, Y. M. and Kim, K. G. 2009. Estimating the Greenhouse Gases Emission Rates and their Emission Factors of a wastewater treatment plant with an MLE Precess, J. Kor. Environ. Analy. 12:87-95.

Sa, J. H. 2010. Ammonia flux from cow manure in relation to the environmental factors in livestock facilities. J. Kor. Atmo. Environ. 26:432-442.

Shen, Y., Ren, L., Li, G., Chen, T. and Guo, R. 2011. Influence of aeration on $\mathrm{CH}_{4}, \mathrm{~N}_{2} \mathrm{O}$ and $\mathrm{NH}_{3}$ emissions during aerobic compositing of a chicken manure and high $\mathrm{C} / \mathrm{N}$ waste mixture waste management. 31:33-38.

Snyder, C. S., Bruulsema, T. W., Jensen, T. L. and Fixen P. E. 2009. Review of greenhouse gas emissions from crop production systems and fertilizer management effects. Agric. Ecosys. Environ. 133:247-66.

Su, J., Liu, B. Y. and Chang, Y. C. 2003. Emission of greenhouse gas from livestock waste and wastewater treatment in Taiwan. Agric. Ecosyst. Environ. 95:253-63.

Wang, J., Duan, C., Ji, Y. and Sun, Y. 2010. Methane emissions during storage of different treatments from cattle manure in Tianjin. J. Environ. Sci. 22:1564-69.

Yamulki, S. 2006. Effect of straw addition on nitrous oxide and methane emissions from stored farmyard manures. Agric. Ecosys. Environ. 112:140-145.

Yun, S. and Yu, D. 1998. Quantitative valuation of greenhouse gas of a agriculture livestock production using LCA technique. J. Kor. Organic Agric. 7:17-34.

(Received Jan. 2, 2013; Revised Feb. 18, 2013; Accepted Feb. 19, 2013) 